GLOBAL JOURNAL OF EDUCATIONAL RESEARCH VOL 15, 2016: 49-56

COPYRIGHT@ BACHUDO SCIENCE CO. LTD PRINTED IN NIGERIA. ISSN 1596-6224 www.globaljournalseries.com; Info@globaljournalseries.com

\title{
SCHOOL ABSENTEEISM AMONG PRIMARY SCHOOL PUPILS IN CROSS RIVER STATE: PSYCHOLOGICAL IMPLICATION FOR NATIONAL DEVELOPMENT
}

\section{MELVINA N. AMALU AND KINGSLEY B. ABANG}

(Received 3, August 2015; Revision Accepted 29, September 2015)

\begin{abstract}
Handling of issues and challenges in education at the primary school level believed to be the foundation on which other levels of education rest on will either promote or mar the onward movement of individuals to the other levels of education and the achievement of the objective of education as an instrument for national development. It is against this background that this study attempted to examine the causes of school absenteeism among primary school pupils in the three senatorial zones of Cross River State and proffer solution to remedy the problem. Two research questions were posed to direct the study. Data were collected with the researcher's developed and structured questionnaire captioned: School Absenteeism Questionnaire (SAQ). Multi-stage sampling technique involving stratified and simple random sampling procedures were used to select three hundred and twenty (320) pupils out of three hundred and two thousand, two hundred and ten $(302,210)$ primary six pupils in public schools in Cross River State. They were drawn from 16 primary schools in eight (8) randomly selected local government areas across the three (3) senatorial Zones in Cross River State. Frequencies and simple percentages were utilized to answer the research questions. The finding revealed that financial constraints, lack of interest, illnesses, pampering from family members, location of school were the major causes of absenteeism among pupils. It was recommended among others that parents and their children and/or wards should be counselled on the effect of absenteeism on school performance and its long term consequences on national development.
\end{abstract}

KEYWORDS: School Absenteeism, Pupils, Primary School, National Development, Cross River.

\section{INTRODUCTION}

Regular attendance to school has been described as the pre-requisite for acquiring skills and knowledge required for academic success. It enables a child to learn new information that will help him develop the desired skills and potentials. But it may be difficult for a child to achieve these if he is continuously absent from school. School absenteeism is defined as excused or unexcused absences from school by a child (Reid, 2005). Kearny (2008) puts it to be the persistent, habitual, unexpected and unexplained absences from school of a child of compulsory school age. It then implies that absenteeism occurs when a child absents himself from school for whatever reason or when constant learning is interrupted.

School absenteeism is a serious problem in public schools which takes the form of truancy, school refusal and school withdrawal. Truancy is the absence of a child from school without the knowledge or permission of parents (Cummingham, 2005). The child leaves home

Melvina N. Amalu, Department of Educational Foundational, Guidance and Counselling, University of Calabar, Calabar. Cross River State, Nigeria.

Kingsley B. Abang, Department of Educational Foundational, Guidance and Counselling, University of Calabar, Calabar. Cross River State, Nigeria 
and pretends to be going to school but he turns away and get himself involved in other activities. Truancy is stated by Ihedioha (2003) as a conduct disorder and school disruptive behaviour problem which is an indication of self-assertion or rebellion traceable to the developmental and psychological problem associated with the very young. School refusal as stated by Mcshane, Walter \& Rey (2001) is a situation where a child refuses to attend school even in the face of persuasion and punitive measures from parents and school authorities. The child stays at home with the knowledge of his parents and school administration. This form of absenteeism is always associated with anxiety, phobia, depression and other psychosocial disorder. School withdrawal as pointed out by Loraine \& Austin (2010) occurs when a child is regularly absent from school because the parents intentionally keeps him away from school for their needs and priorities. School absenteeism varies with the level of education. The focus of this study is on the primary school, the subvariables of research related to truancy, school refusal or other studies on the problem of pupils or students missing school for whatever reason will be examined.

Some researchers have identified school absenteeism as a complex and a heterogeneous problem that can be influenced by many factors (Kearny, 2008; Kim \& Streeter, 2006; \& Lauchlan, 2003). Romero (2008) identified negative school environment, anxiety, personality traits, phobia, race/ethnicity and learning disabilities, parental attitude, parental involvement and family poverty as causal factors for school absenteeism. Poor teaching skills, interpersonal conflict, dissatisfaction with school, school disciplinary practices, bullying, teacher's hostile attitude to Antiwi-Danson \& Edet (201 1) were the reasons why students miss school. Ubogu (2004); Estey (2005); Wither (2004) observed that sicknesses, and diseases were the causes of absenteeism. Peer influence, socioeconomic place of residence, were attributed to reasons for skipping school by some children (Reid, 2005: Sarkodie Ntow-Gyan, Bempong \& Saaka 2014). Shortcomings of teaching, disengagement in school experiences, inadequate teaching staff both in quantity and quality, lack of infrastructural facilities vital for quality education according to (Barlow \& Fleischer (201 1), Balouga (2009), Idumange, 2012) are potential factor for absenteeism. While Obanya (2010), Balouga
(2009); Uche \& Maliki (2013) stressed that absenteeism and dropout can be caused by difficult terrain and long distances from school which tempt or force children to withdraw prematurely from school.

Absenteeism as some studies have shown, disturb the dynamic teaching-learning environment. Chronic absenteeism jeopardize the teaching learning environment by creating a dead and tiresome unpleasant classroom environment that make students who come to class uncomfortable and irritable. Absenteeism can be associated with poor academic performance and dropout of school. Pupils who are chronically absent from school are more likely to struggle academically, and have greater chance of becoming dropouts (Smink \& Reimer, 2005; Cash \& Duttweiler, 2005; Matsimoto, 2000; Attwood \& Croll, 2006). In other words, those that missed classes regardless of the reason, loose the opportunity to gain skill and knowledge to be academically successful and subsequent loss of long-run benefits. Dropouts are more unlikely than their peers who finished school to gain employment rather, they live in poverty, receive public assistance in prison or police custody, in poor health, divorced, untimely single parenthood with children who are likely to be dropouts (Shadreck, 2013). Drop outs are also linked to depression and anxiety, and most times resort to use of substance and other problematic and risky behaviours (Kearny 2008; Antwi-Danso \& Edet, 2011). It can also result in failure to fulfil major responsibility in work and school (Abraham, 2004). In their separate studies, (Petrides, Chamarro, Fredrickson \& Furnham 2005; Sigmon \& Nugent, 2001; Ihedioha, 2003, Iwuchukwu, 2013) posited that one of the significant cost associated with absenteeism is violation of social norms and the right of others, criminal activity and display of various anti-social behaviour. Achalu (2003) identified the use of drugs as the biggest cause of dropout. Given that absenteeism has been associated with poor academic performance (Robert, 2007), Chen \& Lin (2008) suggested that attendance to school should be closely monitored, encouraged and enforced. In their own comment Armstrong \& Pearson (2008); Crede Roch \& Kieszczynka (2010) argued that regular attendance to school does not guarantee academic success because many may show up in school without actual participation in learning activities. They went further to advice that teachers and pupils must be 
actively engaged in class attendance to provide the most academic value. Therefore, care must be taken to address absenteeism at the primary education level in order to ensure that pupils enjoy a hitch free teaching and learning processes.

\section{Statement of Problem}

The incidence of school absenteeism among primary school pupils has not been widely reported in Nigeria but it exist in public schools especially those in the rural areas. Discussions and interviews with both pupils and staff of some primary schools revealed that pupils exhibit different dimensions of school absenteeism which has caused some heartaches to some parents, teachers, school administrators and the pupils. Government has made education virtually free, provided some infrastructural facilities, some school through their alumni associations, Parents Teachers Associations (PTA) and philanthropists have organized house to house campaign, seminars and workshops for teachers, parents and pupils on the menace caused by school absenteeism. Some have developed and used several punitive measures on victims. Churches were not left out in the campaign against absenteeism. All forms of absenteeism have a long term consequences on individuals and society at large. Despite all attempts by government, alumni associations, school, churches to minimize the situation, the problem still exist. Hence the decision to undertake this studies on school absenteeism among primary school pupils in Cross River State.

\section{Purpose of the Study}

The study sought to identify:

1. The causes of school absenteeism among primary school pupils.

2. The effect of school absenteeism among primary school pupils.

\section{Research Question}

The following research questions guided the study:

1. What are the causes of school absenteeism among primary school pupils?

2. What are the effects of absenteeism on primary school pupils?

\section{Methodology}

The study adopted a descriptive survey research design. The population of the study comprised of three hundred and two thousand, two hundred and ten (302.210) primary six pupils drawn from sixteen (16) public primary schools in eight (8) randomly selected local government areas across the three (3) Senatorial Zone of Cross River State.

Table 1: Sample of school pupil in three senatorial zones $\mathrm{N}=320$.

\begin{tabular}{llllllll}
\hline S/N & $\begin{array}{l}\text { Senatorial } \\
\text { Zone }\end{array}$ & $\begin{array}{l}\text { Sample } \\
\text { Area }\end{array}$ & $\begin{array}{l}\text { No of school } \\
\text { sampled }\end{array}$ & $\begin{array}{l}\text { No of pupils } \\
\text { sampled }\end{array}$ & Male & Female & Total \\
\hline 1 & Cross River & Odukpani & 2 & 40 & 16 & 24 & 40 \\
& South & Akampka & 2 & 40 & 16 & 24 & 40 \\
& & Biase & 2 & 40 & 16 & 24 & 40 \\
2 & Cross River & Abi & 2 & 40 & 16 & 24 & 40 \\
& Central & Etung & 2 & 40 & 16 & 24 & 40 \\
\multirow{3}{*}{3} & Cross River & Boki & 2 & 40 & 16 & 24 & 40 \\
& North & Bekwara & 2 & 40 & 16 & 24 & 40 \\
& & Obudu & 2 & 40 & 16 & 24 & 40 \\
\hline
\end{tabular}

Source: CRS Statistics Division: Ministry of Education, 2013

The study adopted a multi-stage sampling technique involving stratified and simple random sampling technique. This goes to ensure that every member of the population has equal chance of being chosen. Data for study was generated using a 15 item self developed questionnaire titled: School Absenteeism/checklist (SAQ). The instrument 
had three sections. Section 'A' comprised demographic information of the respondents, Section 'B' contained ten (10) structured items measuring the reasons why students absent themselves from school, section B has 5 items measuring effect of school absenteeism. Respondents were asked to tick Yes or No to the statement, face validity was carried out to ensure that only the item meant to measure what the study intended to measure were certified. The reliability of the instrument using Cronbach Coefficient Alpha was 0.70. The instrument was administered by the researcher and research assistants to the respondents with the permission and approval of school heads in the various schools. The return rate was $100 \%$. Frequencies and simple percentages were used to answer the research questions.

\section{Research Question}

1. What are the causes of school absenteeism among primary school pupils?

Table 2: Causes of school absenteeism among primary school pupils $N=320$

\begin{tabular}{|c|c|c|c|c|c|c|}
\hline $\mathbf{S} / \mathbf{N}$ & & $\begin{array}{l}\text { No of } \\
\text { Yes }\end{array}$ & $\begin{array}{l}\% \text { of } \\
\text { Yes }\end{array}$ & $\begin{array}{l}\text { No of } \\
\text { No }\end{array}$ & $\begin{array}{l}\% \text { of } \\
\text { No }\end{array}$ & Decision \\
\hline 1 & Lack of money for educational materials & 190 & 59 & 120 & 38 & Agreed \\
\hline 2 & Sickness prevents me from going to school & 192 & 60 & 128 & 40 & Agreed \\
\hline 3 & $\begin{array}{l}\text { Long distance from home to school makes me } \\
\text { miss school }\end{array}$ & 188 & 59 & 132 & 41 & Agreed \\
\hline 4 & Fear of teacher prevents me from going to school. & 141 & 44 & 179 & 56 & Disagreed \\
\hline 5 & Fear of examination makes me skip school & 142 & 44.3 & 178 & 55.6 & Disagreed \\
\hline 6 & $\begin{array}{l}\text { Bullying from fellow pupils make me to be } \\
\text { regularly absent from school }\end{array}$ & 130 & 41.1 & 190 & 59 & Disagreed \\
\hline 7 & $\begin{array}{l}\text { Non-attendance due to pampering from family } \\
\text { members }\end{array}$ & 182 & 57 & 128 & 40 & Agreed \\
\hline 8 & Pressure from friends to be absent & 133 & 42 & 287 & 58 & Disagreed \\
\hline 9 & Taking care of sibling keeps me away from school & 134 & 42 & 186 & 58 & Disagreed \\
\hline 10 & Lack of interest in school activities. & 194 & 61 & 121 & 39 & Agreed \\
\hline
\end{tabular}

The table 2 shows that lack of money by parents, sicknesses, school location pampering, lack of interest by the students cause absenteeism to a very high extent with items $1,2,3,7$ and 10 having percentages scores of $59,60,59,57$ and 61 respectively. 


\section{Research Question}

2. What are the effects of school absenteeism on primary school pupils?

Table 3: Effects of school absenteeism on primary school pupils $\mathrm{N}=320$

\begin{tabular}{|c|c|c|c|c|c|c|}
\hline $\mathbf{S} / \mathbf{N}$ & 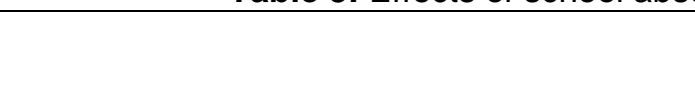 & $\begin{array}{l}\text { No of } \\
\text { Yes }\end{array}$ & $\begin{array}{l}\% \text { of } \\
\text { Yes }\end{array}$ & $\begin{array}{l}\text { No of } \\
\text { NO }\end{array}$ & $\begin{array}{l}\text { \% of } \\
\text { NO }\end{array}$ & Decision \\
\hline 1 & Poor academic performance & 201 & 63.8 & 149 & 37.2 & Agreed \\
\hline 2 & Drop out of school and unemployment & 185 & 57.8 & 135 & 42.4 & Agreed \\
\hline 3 & Use of substance and cannabis & 164 & 51.3 & 156 & 48.8 & Agreed \\
\hline 4 & Anti-social behavior & 170 & 52.8 & 150 & 46.9 & Agreed \\
\hline 5 & $\begin{array}{l}\text { Anxiety, depression and phobia aggression, } \\
\text { cruelty. }\end{array}$ & 180 & 56.3 & 140 & 43.7 & Agreed \\
\hline
\end{tabular}

Table 3 reveals that school absenteeism leads to poor academic performance, school dropout, unemployment, substance abuse and antisocial behaviour, phobia/depression/anxiety. The indication is in the percentage score 201 (63.8), 185 (57.8), 164 (51.3), 170 (52.8) and 180 $(56.3 \%)$ respectively.

\section{DISCUSSION OF FINDINGS}

The finding showed that, sicknesses and diseases are one of the major causes of school absenteeism. The study is in agreement with the finding of (Ubogu 2004; Estey 2008; Wither 2005) who pointed out in their different studies that a child can be absent from school as a result of illness or disease caused by poverty, poor nutrition and poor sanitary condition. He can equally be asked to skip school because of parents' ill health or low vitality. A child who is always sick sometimes loses appetite and as a result, the child may be too weak to engage in any meaningful academic activity.

Also the result of the finding identified lack of interest in school activities. It is in line with the findings of (Elliot, Kratochwill; Cook \& Travers (2000) who stated that interest is an enduring characteristics expressed between a person and a particular activity or object. It then follows that a child who lacks interest in school activity will not be motivated to learn, so he will stay away from school to engage in any activity that interest him most.

The result finding also revealed that as a result of long distance from home to school and difficult terrain, pupils are tempted to be absent. It, is in consonance with the observations of Obanya (2010), Balouga (2009); Uche \& Maliki, 2011 opined that swampy, wetland terrains where utilities and social amenities are epileptic or non-existent, children are easily tempted to leave school before graduation. The finding that pampering influence school attendance negatively is in agreement with finding of Reid (2008) that parental attitude can make a child skip school especially when the parenting style is weak. For bullying, fear of teacher and examination, taking care of siblings and peer influence not to be significant, although surprising shows that with good and effective administrative and management style all those factors are reduced or eliminated and as such will not affect school attendance.

On the effect of school absenteeism, the finding showed that school absenteeism can lead to poor academic performance thereby leading to 
school dropout and affecting their career. It can also undermine societal peace and encourage social vices such as prostitution rape, kidnapping, armed robbery. This finding corroborates with the observation of Okwara-Kalu, Agulanna \& Ojekudo (2013) who identified time wastage, prevention of actual learning, poor academic performance, bullying crime and drug related issues as the effect of school absenteeism. It is either the child is sent out of school for chronic absenteeism or he drops out of school to join his likes which can ultimately affect the career of such child. It implies that school absenteeism has serious setback on teaching-learning processes and can even destroy the future career of a pupil if not checked.

\section{Psychological Implication for National Development}

Education as a driver for national development (Denga, 2015) is the major conduit through which individuals acquire and develop adequate and appropriate knowledge, skills, attitudes, values and behaviour necessary to function optimally as citizens (Uche \& Amalu, 2014). It then implies that a child who is frequently absent from school or class denies himself the opportunity to develop the required knowledge and skills and may end up performing poorly in his academics. If the absences are not well tackled at the early years which is critical in a child's educational career and at the primary level which remain as Obanya (2000) puts it the back bone on which future education is built may result to drop out of school which reduces the chances of the child advancing in his educational pursuit and being employed in a good and well paid jobs in the future. Some of the dropouts live in poverty, poor health, some of them out of frustration and depression engage in illegal ways to make ends meet, some engage in election rigging, political thuggery, cultism, stealing, kidnapping, prostitution, drug abuse, gangsterism and indoctrination into terrorist group. All these according to Anann (2013), disrupts and threatens the peace, security and development of a nation.

Considering the negative effect of school absenteeism on human and schools development there arise a need to seek an effective intervention to minimize or eliminate it. Since absenteeism is a disciplinary problem, conduct disorder and school disruptive behaviour, Cognitive Behaviour Modification
Strategy (CBMS) which is both a proactive and preventive counselling technique that uses the principle of psychology to change unwanted behaviour to desired one can be used. In using CBMS an individual is helped to reverse his perception of the world or his immediate environment and when effectively used, gives the young person an opportunity to talk about himself, how he feels being absent. What informs his being frequently absent from school and with this, he is guided to learn new ways of seeing things? This technique teaches the application of both critical and rational reasoning to young persons and help them reverse their earlier negative attitude and ill held belief.

\section{CONCLUSION}

School absenteeism is an age long phenomenon that has eaten deep into the social fabrics of public sectors of the nation. This study revealed various form of absenteeism in primary schools which include school refusal, truancy and school withdrawal. These maladaptive behaviours are caused mainly by poverty, long distances etc. The main solution is by proactive counselling.

\section{RECOMMENDATIONS}

The future of our country is determined greatly by the young ones we have. However to ensure a better future for Nigeria and the Nigerian educational system, there is need to tackle absenteeism in primary schools, since some of pupils will be leaders of tomorrow through the following ways;

1. Non punitive discipline which gently guides the child instead of threats and punishment should be used.

2. Parents and teachers should learn to cultivate a positive and healthy relationship with the child.

3. More sensitization campaign, seminars, workshop should be organized for parents, pupils and teachers on the importance of regular attendance to school.

4. Government should provide more educational facilities and employ more qualified teachers.

5. Teachers should be sponsored for workshops and conferences and professional advancement for them to acquire more professional skills. 
6. Head teachers should monitor the teachers because some of them are victims of absenteeism and pupil emulates them.

7. There is need for collaboration between parents and teachers on the possible causes of school absenteeism.

\section{REFERENCES}

Achalu, O., 2000. Drug abuse and its implication. In Des Wilson (ed) Cultism: Evil unlimited. A publication of the Peace on Campus Initiative (PCl), University of Uyo.

Annan, K., 2013. Challenge the conventional: Can truth commission effectiveness strengthen peace processes? New York;: Green Tree.

Antwi-Danso and Edet, P. B., 2011. Perceived causes and effect of school dropout among girls in Koforidua Municipality Ghana. The Calabar Counsellor, 5, 5, 1727.

Attwood, G. and Croll, P., 2006. Truancy in secondary pupils: Prevalence, trajectories and pupil perspectives. Research Papers in Education 21,4: 467484.

Balouga, J., Feb 2009. The Niger Delta: Diffusing the time bomb. International Association for Energy Economics 8-11.

Barlow, J. and Fleischer, S., 2010. Student absenteeism, whose responsibility? Innovation in Education and Teaching International 48, 3: 227-237.

Bond, G., 2004. Tackling student absenteeism. Research findings and recommendations for schools and local communities. Retrieved:

http..://www.hw//en,com.au/text/l 062829817063 3396/up-loaded files//I 123252485002929.doc) 14/05/15.

Bowen, N. K., Bowen, G. L. and Ware, W. R., 2002. Neighbourhood social disorganization, families and the educational behaviour of adolescents. Journal of Adolescent Research, 17: 468-490.

Cash, T. and Duttweiler, P., 2005. Planning collaboration and implementation strategies for truancy programme National Prevention Centre 3-22.

Chen, J. and Lin, T. F., 2008. Class attendance and exam performance: $A$ randomized experiment. Journal of Economic Education 39, (3): 213-227.

Crede, M; Roch, S. G. and Kieszcynka, U. M. 2010. Class attendance in college. A review of the relationship of class attendance with grades and student's characteristics. Review of Educational Research, 80, (2): 272-295.

Cummingham, M. M., 2005. A study of school enrolment and dropout rate in four rural primary schools in St. Mary Jamaica. Unpublished Master's Thesis. University of West Indies, Mona. Jamaica.

Denga, D. I., Sept, 2015. Knowledge Integration: Catalysis for national development. A lead paper presented at the $5^{\text {th }}$ National Conference of Faculty of Education. University of Calabar. $1^{\text {st }}-5^{\text {th }}$ Sept. 2015.

Etsey. K., 2005. Causes of low academic performance of primary school pupils in the Shama Submetro of Shama Ahanta East Metropolitan Assembly (SAEMA) in Ghana Retrieved from http://'www.saga. cornell.edu/saga/educ.conf etsey.pdf.

Goldstein. J. S., Little and Akin-little A. 2003. Absenteeism: A review of the literature and school psychology role. The California School Psychologists, 8, 127139.

Idumange, J., Feb. 2012. Free education in Bayelsa State: Walking the talk. The Will www.thewillnigeria.com/opinion.

Retrieved July 31, 2013.

Ihedioha, L. N., 2003. Contingency contract and modelling in the management of truancy among primary school pupils. 
Unpublished Ph.D Dissertation Abia State University.

Kearny, C., 2008. School absenteeism and school refusal behaviour. A review and suggestion for school based health professional. Journal of School Health 76, (1): 3-7.

Kim, J. S. and Streeter, C. L., 2006. Increasing school attendance: Effective strategies and intervention. In C. Frankin, M. B., Harris, P. Alien Measres (Ed). The School Services Sourcebook. A guide for school based professional. New York: Oxford University Press, (pp. 397-404).

Lauchlan. F., 2003. Responding to chronic nonattendance: A review of intervention approaches. Educational Psychology in Practice 19, (7): 133-146.

Matsimoto, D., 2000. Culture and psychology (2nd ed.). USA: Wadsworth Thompason Learning.

McShane. G., Walter, G. and Rey, J. M., 2001. Characteristics of adolescent with school refusal: Australian and New Zealand Journal of Psychology 35, (6): 822-826.

Moore. S., Armstrong, C. and Pearson, J. 2008. Lecture absenteeism among students in higher education: A valuable route to understanding student motivation. Journal of Higher Education Policy and Management 30, (1): 5-24.

Obanya, P., 2010. Planning and managing access to education. The Nigerian experience: Open Seminar Series. Centre for International Education Department of Education, University of Sussex, England.

Okwarra-Kalu, C. E., Agulanna, G. G. and Ojekudo, F., 2013. Parents, perception of primary school discipline: Implication for teaching and learning. The Nigerian Psychologists 11, (1): 206-214.

Petrides, K. V., Chamarro-Premuzic, T. Frederickson, N. and Furnham, A., 2005. Explain individual differences in scholastic behaviour and achievement. British Journal of Educational Psychology 75, 239-255.

Reid. K., 2005. The causes, view and traits of school absenteeism and truancy. Research in Education, 74: 59-84.

Robert, Jr. L. L., 2007. Class attendance: Is it important? Paper submitted in Partial Fulfilment of the Master Teacher Programme conducted by the centre for teaching excellence. United State Military Academy, West Point, N. Y.

Romero, D., 2008. Do students go to class? Should they? Journal of Economic Perspectives 7, (3): 167- 174.

Sarkodie, N. A., Ntow-Gyan; Bempong and Saaka 2014. Assessment of absenteeism and lateness among hospitality and tourism students in Sunyani Polytechnic. Journal of Education and Practice 5, (16): 16-25.

Shadreck, M., 2013. School based factors and the dropout phenomenon. A study of Zhomba cluster secondary schools in Gokwe-district of Zimbabwe. Journal of Education and Social Research 3, (1): 51-60.

Smink, J. Reimer, M., 2005. Fifteen effective strategies for improving student attendance and truancy prevention. National Dropout Prevention Centre Network 1-20.

Ubogu, R. E., 2004. The causes of absenteeism and dropout among secondary school students in Delta Central Senatorial District of Delta State. Unpublished Ph.D Thesis. Abraka: Delta State University.

Uche, R. D and Amalu, M. N., 2014. School dropouts among males of secondary school-age in Anambra State. Education for Today. 10:122-129.

Uche, R. D. and Maliki, A. E., 2013. Niger Delta Youth militancy - the Bayelsa experience: Antecedent and consequences and counselling implication. Journal of Social Sciences 28, 1, 73-76 
